\title{
WAR IN OUTER SPACE: NATURE AND IMPACT OF THE ROMAN WAR EFFORT IN SPAIN, 218/217-197 BCE
}

\author{
Frederik J. Vervaet and Tony Naco Del Hoyo
}

\section{Introduction}

In 219 BGE, a Roman senatorial commission was sent to Carthage to hand over a threatening complaint about the recent conquest of Sagunt, Rome's most faithful ally on the Iberian Peninsula. ${ }^{1}$ In consequence of the Carthaginian Senate's decision to back Hannibal's policy of aggression, a powerful consular army was sent to North-eastern Spain in 218, as a strategic response to thwart Hannibal's march on Italy in what was rapidly evolving into a 'global war' all across the Western Mediterranean, comprising Italy, Sicily, Sardinia, Corsica, Illyria, Africa and, last but not least, the Iberian Peninsula. At the outbreak of the Second Punic War, large tracts of Spain already were an integral and important part of Carthage's sphere of power, as the Barcids had firmly established Carthaginian control of the Southern part of the peninsula. From the Roman geopolitical point of view, however, the war against the Carthaginians and their sundry allies in Spain really was a kind of 'war in outer space'. This paper will indeed argue that both the geographical conditions and the extent of the Spanish theatre of war would deeply affect the nature and impact of the Roman presence in Spain, and this not only during the Second Punic War and its immediate aftermath, but also for the following two centuries.

Both the tremendous strain the war in Italy and Sicily put on Rome's limited number of regular officials cum imperio and the importance of the 'Spanish front' impelled the Senate to have the People create a remarkable series of proconsulatus extraordinarii. Therefore, the first part of this paper will clarify the overall constitutional framework of the Roman presence in Spain from 217 to 197 BGE. After a brief conspectus of

${ }^{1}$ Polybius 3.15.12; Livius 21.9.3ff; Appianus Iberica 10; D. Hoyos, Hannibal's Dynasty. Power and politics in the Western Mediterranean, 247-183 BG (London \& New York 2003), 96-97, n. 15. 
the precise nature of these extraordinary commands and the Roman command structure in Spain, we will next focus on the scope of the constitutive popular laws, the authority of the Senate with respect to the decision-making in the popular assemblies and the commanders in the field, and a few important aspects of the settlement of 198/197. Finally, the second part of this paper will scrutinize the war economy policies applied by the Roman commanders, in particular with respect to the overall management of the war effort and its consequences for the armies and civil populations that were involved either directly or indirectly.

The commands in Spain from 218/217 to 197 BCE: constitutional aspects

a. The extraordinary proconsulships in Spain from 217 to 197: nature and command structure

In 217, in spite of Hannibal's successful invasion of Italy and its formidable challenges, the Senate took a couple of bold and consequential decisions. First, the Senate decided to vigorously carry on the war in Spain. This means that the Senate sanctioned the consul P. Cornelius Scipio's historic decision to send his older brother Gnaeus ahead with the bulk of the consular army before speeding back to Italy in 218 . Secondly, the Senate pragmatically solved the resulting structural lack of regular (pro-) magistrates by creating a series of extraordinary proconsulates. Probably around the time of P. Scipio's prorogatio imperii in March 217, a popular vote turned his legate Cn. Cornelius Scipio (cos. 222) into a proconsul suo iure by decree of the Senate. ${ }^{2}$ Both from

${ }^{2}$ See Livius 21.17.1 and Polybius 3.40.2 for Spain being decreed prouincia consularis in 218 and assigned to the consul P. Cornelius Scipio, and Livius 22.22.1-3 for the arrangements with respect to his command in 217. For Cn. Scipio's original position as legatus acting under the auspices of his younger brother, see Appianus Iberica 14 (comp. Annibaica 5); Zonaras 8.23 and esp. Livius 21.40.3. As Cn. Scipio was charged with the task of marching the bulk of the consular army into Spain while P. Scipio hurried back to Italy to counter Hannibal (Livius 21.32.3ff.; Polybius 3.49.1; 3.56.6; 3.76.1), it should not be questioned that the latter invested the former with delegated praetorium imperium. J.S. Richardson, The Romans in Spain (Oxford 1996), 25 rightly underlines the historic importance of both the decision of the Senate to dispatch P. Scipio to Spain in 218 and the latter's own decision to still send his brother into Spain with the greater part of his army, in spite of Hannibal's threatening advance on Italy proper. Although Appianus probably confounds the s.c. prolonging the imperium 
Livius' indirect indications and the fact that Cn. Scipio is repeatedly styled imperator, it is obvious that both brothers shared the supreme command in Spain from 217 until their untimely deaths in $211 .^{3}$

In 211, in consequence of the successive deaths of P. and Cn. Scipio, the Senate instructed the tribunes of the plebs to ask the tribes whom they preferred to send with imperium to Hispania and to the army of which Cn. Scipio had been commander-in-chief, the appointee being the propraetor C. Claudius Nero (pr. 212). ${ }^{4}$ In all probability, the important

of P. Scipio with the popular vote investing Cn. Scipio extra ordinem with a consulare imperium in Spain, which probably occurred shortly after the decision to dispatch P. Scipio (again) to Hispania, his representation of the facts in Iberica 15 \& Annibaica 8 also strongly suggests a popular vote with respect to the Spanish command in 217 . The fact that Livius does not record the vote of a decree and a subsequent lex concerning the command in Spain need not necessarily imply that no such proceeding took place. For the majority of 218 and the beginning of 217, Livius is actually fully absorbed with the dramatic theatre of war. Only after the defeat of Flaminius does Livius return to the events in Rome, since the appointment of dictator Q. Fabius Maximus Verrucosus heralded a new phase in the war.

${ }^{3}$ For both commanders jointly wielding the supreme command (the summum imperium auspiciumque), see Livius 23.26.2 (216 BGE - comp. also Polybius 8.1.(3)4); 23.29.17; 23.48.4; Livius 25.32 (comp. Appianus Iberica 16). For Cn. Scipio being styled imperator, see Livius 23.27.11; 24.48; 25.32.1ff.; 25.35.4; 25.37.9-11; 27.4.6 (comp. also 26.2.5 and 26.18.3). In 28.32.6f. (206 BGE), Scipio Africanus explicitly refers to the Scipionum nomini auspiciisque. Therefore, W.F. Jashemski, The Origins and History of the Proconsular and the Propraetorian imperium to 27 BC (Chicago 1950), 22f.; T.R.S. Broughton, The Magistrates of the Roman Republic 1 (New York 1951), 245; 247, n. 10 (see also op. cit., 250 and 260); G.V. Sumner, 'Proconsuls and provinciae in Spain 218/17-196/5 вG', Arethusa 3 (1970), 86; 88; J-M. Roddaz, 'Les Scipions et l'Hispanie', Revue des Études Anciennes 100 (1998), 343f. (with reference to Polybius 3.97.4) rightly suggest that Cn. Scipio must have commanded pro consule from 217 at the latest. Contra, e.g., Th. Mommsen, Römisches Staatsrecht, 2. Band (Leipzig 1887, 3rd ed.), 652, n. 2 and R. Feig Vishnia, State, Society and Popular Leaders in Mid-Republian Rome 241-167 BC (London \& New York 1996), 65; 221 n. 60, who argue that Cn. Scipio remained subordinate to Publius as the latter's legate; R.C. Knapp, Aspects of the Roman Experience in Iberia, 206-100 BC (Valladolid 1977), 83-88 and J.S. Richardson 1996, op. cit. (n. 2), 36; 29f., who believe that Cn. Scipio only exercised an independent (i.e., 'non-delegated') 'propraetorian' command from 212. T.C. Brennan, The Praetorship of the Roman Republic (Oxford 2000), 155; 313 n. 7, however, steers a middle course by arguing that Cn. Scipio was promoted from legatus to "a commander with (praetorian) imperium by means of lex 'de imperio' voted in 217. R. Develin, 'The Roman Command Structure and Spain 218-190 вc', Klio 62 (1980), $356+$ n. 9, makes the equally implausible suggestion that Cn. Scipio was first vested with "propraetorian imperium" by virtue of delegation by Publius, "which was in 217 not only confirmed and prorogued by popular vote, but was also raised to proconsular status". See the forthcoming monograph (Vervaet) on "The Principle of the summum imperium auspiciumque under the Roman Republic', for an exhaustive discussion of the generally ignored though consequential Republican constitutional principle of the summum imperium auspiciumque.

${ }^{4}$ For Nero's appointment to the Spanish command by means of a plebiscitum ex s.c., see Livius 26.2.5f. (comp. 26.18.2); Zonaras 9.7; Appianus Iberica 17; Develin 1980, 
decision to replace both Scipiones by a single supreme commander was prompted by two strategic considerations. In Iberica 17, Appianus points out that the result of Nero's failure to turn the tide in Spain "was that, although they [i.e., the Romans] desired to, they were unable to evacuate the Iberian Peninsula, for fear that the war there would be transferred to Italy". Immediately upon this explanation, Appianus goes on to describe the proceedings leading to the election of Scipio Africanus. Obviously, many influential senators were in favour of abandoning Spain altogether in consequence of the disastrous defeat of P. and Cn. Scipio. Since, however, such a decision would have seriously increased the risk of a new Carthaginian invasion of Northern Italy, the Senate eventually decided to carry on the war in Spain, henceforth under the command of a single commander-in-chief. Secondly, this reversal was doubtlessly also dictated by the critical situation in Spain itself, which clearly required a singular and undisputed high command. In this way, any possibility of dangerous disputes between imperatores commanding on a footing of equality (pari imperio) could be ruled out.

After Nero had failed to fully exploit his successes against Hasdrubal, the Senate decided to get him replaced. However, as the senators could not come to an agreement as to who was to be sent to Spain but all agreed that a successor to this crucial command was to be chosen with extraordinary care (extraordinaria cura), the Senate finally decided that the consuls should organise an election in the comitia centuriata. When the young but charismatic P. Cornelius Scipio, son of the recently slain P. Scipio, offered himself as a candidate, the centuriae voted that he should pro consule have the (summum) imperium in Hispania. ${ }^{5}$ Whereas

op. cit. (n. 3), 358 and Brennan 2000, op. cit. (n. 3), 156. Nero's imperium was doubtlessly raised from praetorium to consulare. The dispatch of C. Claudius Nero is generally perceived as a transitional measure aimed at the consolidation of the position of the Roman army in Spain pending the arrival of a more 'permanent' commander; see, e.g., Knapp 1977, op. cit. (n. 3), 88; Develin 1980, op. cit. (n. 3), 359 (cf. infra) and Brennan 2000, op. cit. (n. 3), 156. However, given (1) the fact that the Senate subsequently gave Claudius adequate means to discharge his duties (Livius 26.17.1f.), (2) the scope of his remarkably successful campaign (Livius 26.17.2-16), and (3) the fact that Livius clearly refers to a procedure aiming at the appointment of permanent successor to the command of Cn. Scipio in 26.2.5, there is every indication that his appointment was originally not meant as a provisory measure.

${ }^{5}$ Livius 26.18.2-11. See also Livius 26.41.18 for Scipio Africanus receiving his consulare imperium by virtue of a lex centuriata. Since Scipio was in all likelihood elected at the outset of the consular year 210, the consuls who called for the vote in the comitia centuriata at the behest of the Senate were none other than M. Claudius Marcellus and M. Valerius Laevinus. This means that Scipio got his Spanish command by virtue of a lex Claudia Valeria. 
Livius' summary clearly shows that the lex simply named a proconsul who received the supreme command in prouincia Hispania, the summary but valuable accounts of Appianus and Zonaras contain the real key to the solution of the problem of (the procedure of) Scipio's appointment. Appianus and Zonaras clearly indicate that especially Hasdrubal's cunning escape from the Black Rocks and the ensuing recovery of Carthaginian power in Spain caused increasing panic and dissatisfaction in Rome. As Livius unambiguously shows in 26.18.2-4 that the initiative to appoint a successor to the command of the unfortunate Claudius Nero was taken by the Senate in the first place, it is obvious that the greater part of that body was displeased at the way Nero had handled matters in Spain. Although it was eventually young P. Scipio who got the Spanish command in 210, both Livius' representation and the fact that the Senate decided to send the seasoned propraetor M. Iunius Silanus (pr. 212) along with Scipio show that it was the Senate's original idea to replace Claudius Nero by a senior, more experienced senatorial commander. On account of the Senate's inability to work out a solution by themselves, the bitter earnest of the situation in Spain and especially their aim to assign the Spanish command to a senior senatorial commander, the Senate by way of exception decided to have the consuls put the matter to the comitia centuriata instead of working through the tribunes of the plebs. By doing so, the Senate probably also hoped to forestall any possible popular agitation about the appointment of another commander-in-chief for Spain, expecting that the more 'conservative' comitia centuriata would ensure the appointment of a mature and skilled commander. This view is further strengthened by the fact that Scipio had to defend his election before a contio after a number of influential senior senators had cast serious doubts on his suitability. Last but not least, it is important to ascertain that although the Senate redefined the propraetor's imperium as consular and entitled him to share the summum imperium in Spain, Silanus from the very outset voluntarily left the supreme command to Scipio alone. ${ }^{6}$

${ }^{6}$ For senior senators questioning Scipio's capabilities, see Appianus Iberica 17f.; Zonaras 9.7. For the pro praetore Silanus being subsequently appointed by the Senate to assist Scipio on a footing of equality (pari imperio), his imperium being redefined as consular, see also Livius 26.19.10f.; esp. 28.28.14 (eodem iure, eodem imperio - comp. Polybius 10.6.7 and Livius 22.27.6). For Silanus leaving the supreme command in Spain to P. Scipio from 210 to 206, see Livius 28.1.5; 28.13.3; 28.14.15; 28.34.12; comp. 28.26.7 and 28.27.12; see also 28.16.9-15 (esp. 14: ductu atque auspicio P. Scipionis pulsi Hispania Carthaginienses sunt) and 28.38.1 (Haec in Hispania P. Scipionis ductu auspicioque gesta); and Appianus Iberica 26; 28; 30. 
Although many scholars have questioned the historicity of Scipio's election in the comitia centuriata, ${ }^{7}$ a confluence of exceptional circumstances induced the Senate not only to advise the creation of another extraordinary proconsulate, but also to do so by virtue of a vote in the comitia centuriata. This strongly suggests that appointments of imperators extra ordinem were 'normally' made by the concilium plebis. Apart from Scipio's manifest popularity with the people, and the fact that he had already distinguished himself during the battle of Ticinus, ${ }^{8}$ there may have been some other very good reasons explaining the acceptance of the undaunted candidateship of a twenty-four years old aedilicius. J.-M. Roddaz lucidly points to the fact that P. and Cn. Scipio had contracted several private alliances with local dynasts, and built up a clientela among Spanish ciuitates, and that risings occurred in 206 and 205, respectively provoked by rumours of Scipio Africanus' death and mere contempt of his successors. ${ }^{9}$

In 206, the year after the battle of Metaurus, the Senate doubtlessly felt that the time had come to relieve Scipio and Iunius Silanus of their commands in Spain. Although Livius unfortunately records nothing to the point, the Senate in all likelihood charged the consuls to recommend the tribuni plebes to provide extra ordinem for two new commanders by means of a plebiscitum. In 29.13 .7 (204), 30.41.4f. (201), and 31.50 .11 (200), Livius indeed relates that the imperium of L. Cornelius Lentulus and L. Manlius Acidinus was prorogued in 204 by virtue of a plebiscitum, and that both proconsuls were succeeded in 201 and 200 respectively by means of a plebiscitum. ${ }^{10}$ G.V. Sumner also rightly explains that the ovations decreed to L. Cornelius and L. Manlius in 200 and 199 successively virtually prove that both commanders had been vested with (full) imperium by popular vote. ${ }^{11}$ Livius' information

${ }^{7}$ L. Lange, Römische Alterthümer (Berlin 1876, 3rd ed.), vol. 2, 178; 708; Mommsen 1887, op. cit. (n. 3), 659, n. 4; Sumner 1970, op. cit. (n. 3), 87 (see also 99, n. 30); Knapp 1977, op. cit. (n. 3), 89f. and R.T. Ridley, 'The extraordinary commands of the Late Republic. A matter of definition', Historia 30 (1981), 281 all believe it really concerns a vote of the plebs.

${ }^{8}$ See Livius 21.46.7ff;; Polybius 10.3.4ff.

${ }^{9}$ Roddaz 1998, op. cit. (n. 3), 352.

${ }^{10}$ Livius 29.13.7. Obviously, for one reason or another, there was no unanimity in the Senate concerning a possible prorogation of the imperium of L. Cornelius and L. Manlius in Spain. Therefore, the Senate eventually decided to put the question of the supreme command in Spain again to the concilium plebis, through the consuls and the tribunes of the plebs.

${ }^{11}$ Sumner 1970, op. cit. (n. 3), 90; 100, n. 76, with reference to Livius 31.20.3f. and 32.7.4. The decree concerning the exploits of L. Manlius was vetoed. Contra 
about the activities of L. Cornelius and L. Manlius strongly suggests that from 206 onward, the supreme command in Spain was shared again, which means that the command structure of the years 217-211 was resumed. At any rate, Livius' words in 29.13.7 seem to imply that the Senate in 204 continued a previously established policy, and that the decision to assign the summum imperium there to two other proconsuls in 206 was taken by the Senate. ${ }^{12}$

At the beginning of 201, however, the Senate formally advised the consuls to urge the tribunes to bring before the People the question who by their command should be commander in Hispania. It is obvious that in March 201, several influential senators wanted to effect an important change of policy with regard to the organization of the command in Hispania, since the authorizing decree contained a few clear lines of action. The tribuni were to ask the tribes to appoint a single proconsul/summus imperator. This appointee was then to enrol a single legion and Latin allies in fifteen cohorts out of the existing two armies. L. Cornelius and L. Manlius were to bring back the veterans to Italy. ${ }^{13}$ Although the tribuni plebis indeed convened the concilium plebis again at the behest of the consuls and the Senate, they clearly adopted a surprisingly independent stance. On the basis of what we know about C. Cornelius Cethegus, Cornelius Lentulus' successor, ${ }^{14}$ and the fact that sometime during the first months of 200, only L. Cornelius Lentulus returned from Spain, ${ }^{15}$ it is clear that the Comitia appointed a successor to (only) L. Cornelius Lentulus, and at once confirmed the

\footnotetext{
Develin 1980, op. cit. (n. 3), 361f., who believes that L. Cornelius and L. Manlius were vested with praetorium imperium in 206 by means of delegation by either Scipio or the praetor urbanus. Develin thinks that Cornelius Cethegus (cf. infra) was also given a praetorium imperium in 201, "which was subsequentedly extended and augmented for 200". Concerning Cn. Cornelius 'Lentulus' (Develin believes that not Cn. Cornelius Blasio but Cn. Cornelius Lentulus actually departed for Spain in 199, cf. also infra) and L. Stertinius, who were proconsul in 199, Develin argues that they "could have easily been given delegated imperium at the end of 200, after Cethegus' election, which authority the plebs now elevated", and explains that as far as delegation was concerned, "The arrangements and nominations could easily have been made without the participation of the plebs." For a similar view, see, for example, Feig Vishnia 1996, op. cit. (n. 3), 67f.

${ }_{12}$ Since the Senate in 204 simply advised the tribunes to ask the People which two men it wished sent out to Spain, it is only logical to suppose that in 206 the same question had been brought before the People ex senatus consulto.

${ }^{13}$ Livius 30.41.4f.

${ }^{14}$ See Livius 31.49.7 for the fact that Cethegus won a victory in the Ager Sedetanus in 200 .

${ }^{15}$ Livius 31.20.1.
} 
command of L. Manlius Acidinus. ${ }^{16}$ C. Cornelius Cethegus (cos. 197) most probably assumed his command in the course of 201 after being chosen (i.e., extra ordinem) proconsul in the spring of that year. ${ }^{17} \mathrm{~J} . \mathrm{S}$. Richardson at any rate rightly concludes that the Senate at this moment clearly had the intention of cutting down the Roman army in Spain, both as for the number of troops and the number of imperators, even if the election of $\mathrm{C}$. Cethegus and the staying on of Acidinus meant that no withdrawal was achieved. ${ }^{18}$

At the very end of the consular year 200, yet one more plebiscite was passed with regard to the command in Spain. As C. Cornelius Cethegus was elected curule aedile in absentia, the Senate instructed the tribunes to propose which two men they would order to go to the armies in Spain, in order that C. Cornelius might return to enter upon his office, and that L. Manlius Acidinus might be relieved of his prouincia after many years of service. The tribes ordered Cn. Cornelius Blasio (pr. 197) and L. Stertinius to hold imperium in Hispania with the status

${ }^{16}$ See also Sumner 1970, op. cit. (n. 3), 91: "On the facts recorded it appears that C. Cethegus actually succeeded only L. Lentulus, that Acidinus was left in command, and that Acidinus' army remained in separate existence. If Livius correctly reports the resolution of 201, it must have been modified at some stage." In my opinion, the Senate issued a new decree regarding the armies in Spain after the unexpected result of the vote in the concilium plebis.

17 Broughton 1951, op. cit. (n. 3), 320 indicates that G. Cornelius was "probably" chosen in 201 to succeed L. Cornelius Lentulus in Spain. It does not strain belief that L. Cornelius Lentulus was succeeded around the late spring/early summer of 201, only to arrive in Rome with his veterans in the first months of 200. The use of the imperfect of obtinere in Livius 31.49.7 strongly suggests that C. Cornelius had taken up his command in Spain before 200.

${ }^{18}$ J.S. Richardson, Hispaniae: Spain and the development of Roman imperialism 218-82 BC (Cambridge 1986), 68-70. Richardson, however, explains this course of things as an example of "the gap between the thinking about Spain which went on in Rome, and in particular in the Senate, and what was actually happening on the spot." Richardson indeed believes that the reversal occurred in Spain rather than in Rome, and that it is quite possible that it was not until after Cethegus had arrived in Spain to take up his provincia that the decision was made to continue with two proconsuls and two armies. As the sources provide no proof for this conjectural and rather far-fetched hypothesis, there are no good reasons to doubt that the main features of strategy and policy were chiefly devised in Rome. See also Richardson 1996, op. cit. (n. 2), 46f. for the hypothesis that "given the size of the territory controlled by the Romans in 201, to say nothing of the immensity of the hinterland, it is more likely that the Senate intended this reduction to be the first stage of a phased withdrawal than the start of a long-term occupation by one legion and a few cohorts of allies." Richardson reiterates the unlikely suggestion that the reversal of the original intention took place in situ, after Cethegus had reached Hispania, after consultation with L. Cornelius Lentulus and L. Manlius Acidinus. On p. 50, however, Richardson propounds that it may have been the Senate's intention in 201 to have the one commander who was to remain to maintain Roman control of a considerable stretch of the coastal strip. 
of proconsuls. ${ }^{19}$ The Senate's decision to have the Comitia appoint two commanders at any rate indicates that by now it no longer considered reducing the Roman presence in Spain. Quite possibly, the Senate was already contemplating more orthodox ways to organize Rome's longterm presence on the peninsula.

In sum, this brief survey of the successive commands in Hispania during the Second Punic War results in the following scheme for the command structure in Hispania from 218 to $197:^{20}$

\begin{tabular}{|c|c|c|c|}
\hline 218 & $\begin{array}{l}\text { By decree of } \\
\text { the Senate }\end{array}$ & $\begin{array}{l}\text { One summus } \\
\text { imperator }\end{array}$ & $\begin{array}{l}\text { The consul P. Cornelius } \\
\text { Scipio }\end{array}$ \\
\hline $217-211$ & $\begin{array}{l}\text { By decree of } \\
\text { the Senate } \\
\text { and by law }\end{array}$ & $\begin{array}{l}\text { Two summi } \\
\text { imperatores }\end{array}$ & $\begin{array}{l}\text { The proconsuls P. and Cn. } \\
\text { Cornelius Scipio (cos. 222) }\end{array}$ \\
\hline $211 / 210$ & $\begin{array}{l}\text { By law } \\
(\text { ex } \\
\text { s.c. })\end{array}$ & $\begin{array}{l}\text { One summus } \\
\text { imperator }\end{array}$ & $\begin{array}{l}\text { pro praetore pro consule } \\
\text { G. Claudius Nero }(p r .212)\end{array}$ \\
\hline $210-206$ & $\begin{array}{l}\text { By law and } \\
\text { decree of } \\
\text { the Senate } \\
\text { By mutual } \\
\text { agreement }\end{array}$ & $\begin{array}{l}\text { Two summi } \\
\text { imperatores } \\
\text { One summus } \\
\text { imperator }\end{array}$ & $\begin{array}{l}\text { The proconsul P. Scipio Afri- } \\
\text { canus (cos. 205) and pro praetore } \\
\text { pro consule M. Iunius Silanus } \\
\text { (pr. } 212 \text { ) } \\
\text { P. Scipio Africanus }\end{array}$ \\
\hline $\begin{array}{l}206(-204)- \\
201\end{array}$ & $\begin{array}{l}\text { By law } \\
(\text { ex } \\
\text { s.c. })\end{array}$ & $\begin{array}{l}\text { Two summi } \\
\text { imperatores }\end{array}$ & $\begin{array}{l}\text { The proconsuls L. Cornelius } \\
\text { Lentulus (cos. 199) and } \\
\text { L. Manlius Acidinus (pr. 210) }\end{array}$ \\
\hline $201-200 / 199$ & By law & $\begin{array}{l}\text { Two summi } \\
\text { imperatores }\end{array}$ & $\begin{array}{l}\text { The proconsuls C. Cornelius } \\
\text { Cethegus (cos. 197) and } \\
\text { L. Manlius Acidinus (pr. 210) }\end{array}$ \\
\hline 200/199-197 & $\begin{array}{l}\text { By law } \\
(\text { ex s.c. })\end{array}$ & $\begin{array}{l}\text { Two summi } \\
\text { imperatores }\end{array}$ & $\begin{array}{l}\text { The proconsuls Cn. Cornelius } \\
\text { Blasio } \\
\text { (pr. 194) and L. Stertinius }\end{array}$ \\
\hline
\end{tabular}

${ }^{19}$ Livius 31.50.6-11. See Livius 33.27.1-5 for the fact that only Cornelius Blasio celebrated an ovation shortly after the beginning of the consular year 196, whereas L. Stertinius, his fellow proconsul, did not even take the trouble to petition for a triumph. Fortunately, the ouatio celebrated by Cn. Cornelius Blasio happens to be also epigraphically on record, see G.V. Sumner, 'A New Reading in the Fasti Triumphales Capitolini', Phoenix 19 (1965), 24-26, contra Th. Mommsen, CIL 1 (Berlin 1863), 568 and Mommsen 1887, op. cit. (n. 3), 652, n. 4; A. Degrassi, Inscriptiones Italiae 13, 1, 78f. The inscription bears testimony to the particular pride taken by Cn. Cornelius in his proconsulate being constituted 'extra ordinem'.

${ }^{20}$ Contra Sumner 1970, op. cit. (n. 3), 85; 87-89; 92, where it is argued that there were two proconsular commands in Hispania from from 217 till 197, "one of them 
b. The scope of the constitutive lawes

The above shows that the laws that created the extraordinary commands in Spain simply defined nominatim whom was to have imperium 'pro consule' in a definite prouincia. In light of what Livius records about the consecutive votes of the Second Punic War and the similar procedure Cicero attests in Philippicae 11.18 pertaining to the assignment of the command against Andronicus in 131, it is clear that either any interested citizen was formally called on to stand up for a certain command between the promulgation of the bill and the actual rogatio, regardless of his current official status, ${ }^{21}$ or the bill itself provided for the allocation of a certain command to a certain individual. ${ }^{22}$ The result of, for example, the votes of 204 and 201, shows that it was perfectly feasible for candidates to stand in absentia. Those who were extra ordinem invested with imperium consulare logically carried the official title of proconsul.

\section{c. The authority of the Senate and the decision-making in the popular assemblies}

Although, at first sight, one would think that the decision-making in the concilium plebis proceeded fully in conformity with the preliminary directives of the Senate, the discussion supra induces a more nuanced conclusion. During the Second Punic War, the Senate indeed governed most of the decision-making in the Comitia. The quite often recorded procedure of the Senate advising the consuls to arrange with the tribunes of the plebs that they should bring a certain question before the Comitia was doubtlessly standard around the time of the Second Punic War. At all events, it is of great importance to note

depending on popular election of privati (from Cn. Cornelius Scipio to Cn. Cornelius Blasio), the other beginning as a command assigned by the Senate to magistrates or promagistrates with imperium prorogued (P. Cornelius Scipio, cos. 218, C. Claudius Nero, pr. 212, M. Iunius Silanus, pr. 212, pro pr. 211), and changing later to popular election of privati (L. Manlius Acidinus, L. Sertinius)", with the implicit suggestion that the former command ("command A") was superior to the latter ("command B"), at least until the election of Manlius Acidinus.

${ }^{21}$ This was apparently the case in e.g. 211 (C. Claudius Nero), 210 (P. Scipio Africanus), 206 (L. Cornelius Lentulus and L. Manlius Acidinus), 204 (idd.), 201 (C. Cornelius Cethegus and L. Manlius Acidinus), 200 (Cn. Cornelius Blasio and L. Stertinius) and 131 .

${ }_{22}$ This was probably the case in 217 (Cn. Scipio), perhaps in 205 (P. Sempronius Tuditanus? See Livius 29.12.3-15), and certainly in 215 (M. Claudius Marcellus: see Livius 23.30.17-19.). This would also be the case in e.g. 107 (C. Marius), 88 (C. Marius), 77 (Cn. Pompeius), 67 (Cn. Pompeius), 66 (id.), and 57 (Cn. Pompeius). 
that in 217, 211,210, 206, 204, 201 and 200, the leges regarding the supreme command in Spain were always passed on the initiative of the Senate, which was doubtlessly also the case for the extraordinary proconsulships of M. Claudius Marcellus and Sempronius Tuditanus in 215 and 205. Especially Livius 30.41.4f. offers a striking example of how the Senate, if necessary, took the initiative to involve the Comitia in the decision-making within a preconceived framework, although this instance necessitates an important annotation.

A number of indirect or secondary but valuable indications in the account of Livius and, to a lesser extent, Appianus and Dio Cassius, indeed point to the fact that during the Second Punic War some important tensions and frictions arose between the Senate on the one hand, and, on the other hand, the decision-making in the Comitia at the instigation of/for the benefit of charismatic protagonists like M. Marcellus and Scipio Africanus. At the outset of 210, Scipio's rather unexpected election by the comitia centuriata was contested by the powerful senatorial seniores to such a degree that Scipio decided to call for an additional contio to strengthen his position. After Scipio's position as proconsul and summus imperator of Spain had become unquestionable in this way, the Senate sent the senior praetorius M. Iunius Silanus along with Scipio, obviously with the intention of providing Scipio with a more mature counsellor and of having a kind of 'supervisor' in the field. The Senate moreover raised the imperium of pro praetore Silanus to the level of a consulare imperium and entitled him to share the supreme command, which, among other things, must have served the purpose of strengthening his position vis-à-vis young P. Scipio. At all events, Scipio departed for Spain in 210 against the will of an important and influential part of the Senate, armed with the powerful and quite exceptional legitimation of a lex centuriata. The careers and extraordinary prouinciae/ imperia of C. Claudius Nero and especially M. Claudius Marcellus and P. Scipio Africanus reveal that even after the crushing defeats at Lake Trasimene and Cannae in 217 and 216, the advocates of an aggressive military policy could continue to depend on the undaunted support of the Roman People, and that the protagonists of the hawkish faction in Rome eventually did not refrain from making use of their popularity among the commons in order to pressure the Senate and, if necessary, obtain imperium and/or prouincia 'extra ordinem'.

Nonetheless, the authority of the Senate remained by far the foremost factor in the Roman decision-making process during the Second Punic War. Polybius in 6.51.5f. expressly explains the Roman victory 
on the basis of the fact that the Roman Senate managed to keep its control of the consilia publica, whereas in Carthage, the multitude had already acquired the chief voice in deliberations. Although A. Lintott emphasizes that the role of the Comitia during the Second Punic War should not be underestimated, he argues that in spite of a concentration of command in the hands of a limited number of aristocrats, the position of the Senate was actually reinforced by the need to coordinate strategy over several theatres of war with social and economic policy at home. In this respect, it is very important to make a few important clarifications. First, the Senate never lost its important prerogatives to allocate the ornatio prouinciae and to define the duration of the commands in Spain, even if the commanders involved were appointed by virtue of popular law. ${ }^{23}$ Polybius indeed strongly emphasizes in 6.15.4-8 that the consuls - and, in extensu, all imperators in the field - were dependent on the Senate in terms of ornatio prouinciae (the allocation of corn, clothing and pay), prorogatio imperii (continuation or supersession) and triumphal honours (the granting of public triumphs). This means that the Senate carefully retained all of its most powerful instruments to keep the commanders in Spain in check, regardless of the matter whether it was the Senate or the proconsuls who worked out the actual strategy in Spain. ${ }^{24}$ Secondly, it is important to stress that there is no indication whatsoever that the successive laws concerning the Spanish commands enhanced the imperium of the commanders involved with potestates extraordinariae. Scipio Africanus' decision to cross over to Africa

${ }^{23}$ For senatorial decisions pertaining to the ornatio prouinciae of the commanders in Spain, see Livius 23.48.4f. (P. and Cn. Scipio); 26.17.1f. (C. Claudius Nero); 26.19.10f.; 27.7.17; 27.10.13 and 27.36.12 (P. Scipio Africanus and M. Iunius Silanus). For decrees concerning the duration of the Spanish commands, see Livius 24.10.3; 24.44.4 and 25.3.6 (P. and Cn. Scipio); 27.7.17; 27.22.7 (P. Scipio Africanus and M. Iunius Silanus); 28.45.10; 30.2.7 and 30.27.9 (L. Cornelius Lentulus \& L. Manlius Acidinus). Contra Develin 1980, op. cit. (n. 3), 360 and A.W. Lintott, The Constitution of the Roman Republic (Oxford 1999), 114, who believe that the commands of Scipio and Silanus offer the first known instance of extending a command for more than one year by virtue of a popular vote. The discrepancy between Livius 27.7.17 and 27.22.7 can be easily explained in that the Senate could always revoke, alter or reconfirm its earlier decisions with respect to the term or the formula of the tempus prorogationis of a certain command in consequence of new developments in the field.

${ }^{24}$ Richardson 1986, op. cit. (n. 18), 43 is one of the proponents of the view that although the Senate provided the basic underlay, in terms of command-structure and supplies, the formulation of the policy in Spain was actually the responsibility of the men on the spot. Richardson argues that this was the inevitable result of the remoteness of Spain and the conditions of war. See also p. 55; 56-57 and Richardson 1996, op. cit. (n. 2), 38 for this view. 
and gain over Syphax was taken suo consilio. In Africa, Scipio himself emphasized that he could not treat with an enemy without an order of the Senate (iniussu senatus). ${ }^{25}$ In 205, the authoritative Q. Fabius Maximus bitterly reproached the consul Scipio for having crossed over to Africa because of his own ambition and without a valid ratio publica, and stressed that Scipio had not the slightest official authorization for this undertaking (sine lege... sine senatus consulto).$^{26}$ In light of these considerations and the tremendous cost of the war effort in Italy proper, it should neither be doubted that the exactions imposed on the Spanish ciuitates to provide the troops with stipendium, frumentum and uestimenta concerned ad hoc measures. ${ }^{27}$ Especially from Livius 23.48.4-6; 12 (cf. also infra), it is, however, clear that the Senate normally had to authorize the commanders in the field what provisions precisely they could exact from the local communities. If there simply was no time for senatorial decision-making, such exactions were doubtlessly effectuated rei publicae causa, out of sheer want, and ratified as such by the Senate post factum, either implicitly or explicitly. ${ }^{28}$

\section{d. The settlement of 198/197: regularization of the supreme command}

At the beginning of 197, for the first time six praetors took office, of whom both C. Sempronius Tuditanus and M. Helvius immediately got a Spanish prouincia, with significant forces and orders to send the veterans home and fix the boundaries which should be observed between the nearer and the farther prouinciae. ${ }^{29}$ Although most scholars doubt

${ }^{25}$ Livius 28.17f. (esp. 28.18.3) and Appianus Iberica 29. To our thinking, Livius 29.24.3 (204 BCE) strongly suggests that the Comitia ratified Scipio's agreement with Syphax. It is possible that Scipio put the matter to the vote himself as consul in 205. For Scipio's compact with Syphax, see Livius 28.18.12 and Appianus Iberica 30. Until formal ratification on the part of $S P Q R$, Scipio's treaty was no more than a military convention, possibly formalized by means of an edict.

${ }^{26}$ Livius 28.42.20-22. Fabius perhaps alludes not so much to the fact that Scipio's excursion was not authorized by a supplementary lex (and/or s.c.) in 206, as to the fact that the lex which had vested Scipio extra ordinem with a proconsulate for the war in Spain did not adjudge him any extraordinary potestas in this respect also.

${ }_{27}$ Livius 28.25.6; 28.25.9f.; 28.29.12; 28.34.11 (Scipio Africanus); Livius 29.3.5 and Appianus Iberica 38 (Cornelius Lentulus and Manlius Acidinus in 205).

${ }_{28}$ Richardson 1986, op. cit. (n. 18), $72+$ n. 49 at any rate rightly emphasizes that "at this stage stipendium seems to be still an ad hoc levy to pay the Roman soldiers" rather than a fixed annual sum drawn from the province.

${ }^{29}$ Livius 32.27.6f.; 32.28.2; 32.28 .11 (ut dimitterent ueterem ex Hispanïs militem; et terminare iussi qua ulterior citeriorue prouincia seruaretur). See C. Ebel, 'Dum populus senatusque Romanus vellet', Historia 40 (1991), 443 for a plausible explanation of the fact that the 
that from this year there existed two distinct, clearly demarcated provinces,${ }^{30}$ this remarkable change of policy nevertheless allows for some interesting conclusions.

First, there is an indication that before 197, the Senate regarded Spain as one great command sphere (prouincia). For convenience's sake, however, its commanders from the first doubtlessly proceeded to a rough geographical and strategic delineation of their respective operational spheres in their prouinciae permixtae, ${ }^{31}$ which more or less corresponded with what would later be the separate provinces of Hispania Citerior and Hispania Ulterior, presumably usually ex s.c., or, if need be, on their own authority. ${ }^{32}$ Naturally, this course of things does not exclude that, during the first three decades of the Roman presence in Spain, the commanders-in-chief regularly joined forces or interfered in their mutual spheres of command, rei publicae causa. Secondly, J.S. Richardson rightly points out that the dispatch of two additional praetors to Spain in 197 indicates a definitive change in the attitude of the Senate towards the peninsula. Whereas the earlier policy left room for an easy reduction or even withdrawal of Roman troops, the new arrangements point to strong support for a permanent Roman presence. ${ }^{33}$

geographical definition of the provincial boundaries was not assigned to a commission of senatorial legati cum auctoritate.

${ }^{30}$ Sumner 1970, op. cit. (n. 3), 85; 92-98; Develin 1980, op. cit. (n. 3), 364f.; Richardson 1986, op. cit. (n. 18), 77f.: "The record of events in Spain in 197 and the two years following is certainly confused, and indeed, through to the end of the 190s it appears that, if there were any boundaries fixed, the proconsuls in Spain took little notice of them; but this does not mean that the Senate did not decree that the boundary should be established in 197."

31 See Livius 27.35.10 for this expression referring to geographically identical prouinciae.

${ }^{32}$ Both the fact that, apart from the period $211 / 210$, there were officially always two supreme commanders in Spain and the fact that the Senate did not send off one but two praetors (pro consule) in 197 further suggest that the peninsula was already roughly divided into two spheres of command during the Second Punic war. For similar views, see also Develin 1980, op. cit. (n. 3), 364f. and Richardson 1986, op. cit. (n. 18), 55-57; 66. On p. 67, Richardson speaks in terms of "The command structure of two proconsuls in one provincia".

${ }^{33}$ Richardson 1986, op. cit. (n. 18), 75f. It is quite possible that from 206, after the battle at the Metaurus and the final victory over the Carthaginian army in Spain, the Senate compromised between simply evacuating Spain altogether and pursuing the undeniable interests Rome had built up in this lucrative area over the last eleven years by means of a short-lived 'institutionalization' of the practice of conferring imperia 'extra ordinem'. Brennan 2000, op. cit. (n. 3), 163 makes the plausible suggestion that the conclusion of the Second Punic War must have prompted strong pressure to work out a lasting arrangement for Spain, but that the decision to divide it into two regular provinces was delayed by the outbreak of the Second Macedonian War in 200. To our 
Next, the correlation of the disappearance of the phenomenon of the imperia extraordinaria with the extension of the number of praetorships proves that the practice of investing private citizens extra ordinem with imperium during the Second Punic War and its immediate aftermath did not so much result from a deliberate policy to send the most capable and experienced men where they were most needed, as from a manifest shortage of 'ordinary' imperators (i.e., magistrates and regular promagistrates cum imperio) during a protracted period of warfare on different fronts. ${ }^{34}$ The Senate's decision to retain Spain through a series of extraordinary proconsuls can probably be further explained by the fact that the number of praetors had already been doubled in the early $220 \mathrm{~s},{ }^{35}$ and that it did not take a final decision with respect to the territorial status of Spain before 198.

Finally, the disappearance of the imperia extraordinaria and the second increase in the number of praetorships also marks another important turning point in the history of the Republic. ${ }^{36}$ This quite fundamental change reveals that the Senate had never felt real enthusiasm for imperia constituted extra ordinem. On the contrary, the very fact that the transfer of the Spanish command from extraordinary proconsuls to regular (pro)magistrates coincides with the decision to maintain the Spanish provinces strongly suggests that the creation of imperia extraordinaria was never meant as a durable solution. Doubtlessly, these imperia, being entirely beyond the framework of the traditional cursus honorum and the regular (pro)magistracies, were increasingly frowned at by a majority of the senatorial nobility as an infringement upon the equal claims its members laid on official honores and military gloria. Indeed, the fact that only two of the more influential imperatores extraordinarii of the Second Punic War actually managed to celebrate an ovation powerfully underscores the suspicion that the Senate harboured towards such commands. Precisely because they had taken up their imperium auspiciumque

\footnotetext{
thinking, this suggestion is corroborated by the Senate's decision to have the Comitia appoint two commanders rather than one at the end of 200 BGE (cf. supra).

34 See also Brennan 2000, op. cit. (n. 3), 163: "The Senate had all too few experienced generals to spare in the Second Punic War: Spain was far off and, after 207, not a major military theater."

${ }^{35}$ In the early 220's, the Senate had already decided to double the number of praetorships in order to provide for regular commanders in Sicily and Sardinia: see Brennan 2000, op. cit. (n. 3), 91-95, with a discussion of the implications of this increase for the Roman political and administrative system.

${ }^{36}$ See Richardson 1996, op. cit. (n. 2), 48 for an assessment of the important political consequences of the increase from four to six praetorships.
} 
outside the established order, i.e. extra ordinem, sine magistratu, none of the extraordinary proconsuls of this period was granted a full triumphus publicus, regardless of often resounding victories. ${ }^{37}$

\section{Rome's administrative management of Spanish 'outer space'}

The second major part of this paper aims at demonstrating that, apart from explaining the successful expulsion of the Carthaginians from Spain in 206, the particular way in which Rome conducted its tremendous war effort in Spain during the Second Punic War deeply affected (the nature of its relationship to) local communities. Furthermore, it will be argued that the main features of Rome's military and administrative interference during these first two crucial decades would structurally determine the way Spain was to be governed for the next two centuries.

First, it is important to point out that quite a few Spanish peoples became actively involved in the Hannibalic War, supporting any of both sides ever since 218. In consequence of this involvement, the natives naturally suffered from the consequences of both contenders' ruthless war economy policies, and often even tried to anticipate the next stage of the war. Until the wars of conquest in Spain were finally concluded in 19 BCE, ad hoc exactions in the form of money, mining resources, slaves, food and other commodities sufficed to sustain the Roman war effort and even generated a surplus for generals, soldiers, entrepreneurs, and the aerarium publicum alike. Because of the mobility of the front, the persistent need of appropriate means to fuel the ongoing war effort over such a long period made it virtually impossible for Roman provincial authorities to set up a permanent and stable system of direct taxation over the Hispani, as one might theoretically expect from an expansive empire in the making such as the Roman Republic. ${ }^{38}$ As Rome's first priority was to keep its legions arriving, circulat-

${ }^{37}$ See esp. Livius 28.38.4 (Scipio Africanus in 206); 31.20 .3 (L. Cornelius Lentulus in 200) and Valerius Maximus 2.8.5 for the fact that the Senate obstinately refused to grant full public triumphs to extraordinary proconsuls on the grounds that they had not assumed their victorious commands as magistrates.

${ }^{38}$ T. Naco, Vectigal incertum. Economía de guerra y fiscalidad republicana en el Occidente mediterráneo: su impacto en el territorio 218-133 a.C. (Oxford 2003); T. Naco, 'Vectigal incertum: guerra y fiscalidad republicana en el siglo II a.C.', Klio 87.2 (2005), 366-395. 
ing, fighting and leaving again, it is rather difficult to imagine how a census of taxpayers could be properly organised, and all sorts of lands registered and taxed. In general terms, local towns and communities could only be taxed on a regular basis after a lasting peace had been achieved by Marcus Agrippa's decisive though hard-won victories over Asturians and Cantabrians, those few possible exceptions proving the rule. ${ }^{39}$ Irrespective of how things were done in other Mediterranean regions during the last two centuries of the Republic, Spanish 'outer space' seems to have been managed consistently under more or less the same rules as applied by the Roman generals during the Second Punic War, i.e., the ones of a war economy.

Around 218, the Iberian Peninsula still was of secondary importance to Rome's geopolitical interest in the Western Mediterranean, after Sardinia-Corsica, and, of course, Sicily, the very first 'extra-Italian' provinces to be regularly assigned to Roman magistrates. ${ }^{40}$ Roman military intelligence conceivably disposed of some scarce information concerning the peninsula's geography, its inhabitants and its natural resources yet before the actual landing in the Ibero-Greek city of Emporion. ${ }^{41}$ Naturally, the amount of reliable information grew lesser as regards the inland regions, most of which being probably even completely unexplored at that time. ${ }^{42}$ So far, Spanish contacts with Italy and Rome had been largely limited to private commerce, as

39 A. Orejas \& I. Sastre, 'Fiscalité et organisation du territoire dans le Nord-Ouest de la Péninsule Ibérique: civitates, tribut et ager mensura comprehensus', Dialogues d'Histoire Ancienne 25.1 (1999), 159-188; I. Sastre, 'Ager publicus y deditio: reflexiones sobre los procesos de provincialización', in M. Garrido-Hory \& A. Gonzales, eds., Histoire, espaces et marges de l'Antiquité. Hommages à Monique Clavel-Lévêque II (Paris 2003), 157-192.

${ }^{40}$ M.H. Crawford, 'Origini e sviluppi del sistema provinciale romano', in Storia di Roma. La Repubblica Imperiale II.1 (Torino 1990), 91-96; J.S. Richardson, Hispania y los romanos (Barcelona 1998), 15ff.; Brennan 2000, op. cit. (n. 3), $91 \mathrm{ff}$.

${ }^{41}$ Strabo 3.137; 3.142; 3.160-162; Polybius 3.4; 34.8.4-10; Appianus, Iberica 56-57; 65; 67-69; Orosius 1.2.2; Diodorus. 5.31.1; 5.34.6-7; Plinius Maior, Naturalis Historia 3.2.6; 3.7-17; 4.18-30; Livius 21.43.8; 35.1.5-7; 35.22.5; 39.42; D. Plácido, 'Estrabón III: el territorio hispano, la geografía griega y el imperialismo romano', Habis 18-19 (1987-1988), 243-256. Intelligence and information for the army strategies: I. Haynes, 'Britain's first information revolution. The Roman Army and the transformation of economic life', in P. Erdkamp (ed.), The Roman Army and the Economy (Amsterdam 2002), 111-126.

42 Strabo 3.4.12-13; Plinius Maior, Naturalis Historia 4.34.110-112; M.V. GarcíaQuintela, 'Sources pour l'étude de la Protohistoire d'Hispanie. Pour une nouvelle lecture', Dialogues d'Histoire Ancienne 16 (1990), 181-220; E. Sánchez-Moreno, Vetones: historia y arqueología de un pueblo prerromano (Madrid 2000), 19-40; 227ff. 
archaeological evidence - especially pottery - clearly record. ${ }^{43}$ This is hardly surprising in the case of Sagunt, Rome's most faithful ally in the area. Interestingly enough and very much unlike what would happen during the Roman conquest of the Iberian Peninsula, Rome's fateful treaty with Sagunt was signed at a time when there were no Roman soldiers in the neighbourhood. Therefore, the treaty was probably made to strengthen an old commercial relationship and in anticipation of further Carthaginian expansion in Spain. ${ }^{44}$ The Phoenician towns from the Southwest of the peninsula, however, had long-standing ties with Carthage. After 237, the Barcids had, moreover, become particularly influential in Spain, the strategic foundation of New Carthage around 229 being a powerful demonstration of Carthage's growing power in this part of the Mediterranean. ${ }^{45}$

As regards the real impact of the presence of Roman legions in Spain and its population from 218, two patterns of territorial intervention clearly emerge. On the one hand, offensive military action gradually pushed the oscillating front further towards the Southern and Western parts of the peninsula, progress and temporary retreat being the result of the whims of war. $^{46}$ On the other hand, the original landing ports of Emporion and Tarraco, their hinterlands, and later on also some native towns in the Baetis valley like Castulo, increasingly constituted the earliest Roman hinterland. ${ }^{47}$ Literary sources not only emphasise the fact that Rome created a series of new alliances with local tribes

${ }^{43}$ J. Principal-Ponce, 'Tarraco, las cerámicas del Grupo Hercúleo y el comercio romano-itálico anterior a la Segunda Guerra Púnica', Journal of Roman Archaeology 11 (1998), 233-244.

${ }^{44}$ Richardson 1986, op. cit. (n. 18), 20ff.; P.P. Ripollès \& $\mathrm{M}^{\mathrm{a}}$.M. Llorens, Arse-Saguntum. Historia monetaria de la ciudad y su territorio (Sagunto 2002), 23-30.

45 Scipio's capture of Carthago Nova in 209 was a decisive turning turning point in the war in Spain. In addition to its magnificent natural port, New Carthage held a considerable amount of wealth, weapons and ships, and accommodated several important hostages, which Scipio cleverly used to win the favour and support of many local tribes in the subsequent settlement; see M. Bendala, 'Panorama arqueológico de la Hispania púnica a partir de la época bárquida', in M $^{\mathrm{a}}$.P. García-Bellido \& L. Callegarin, eds., Los cartagineses y la monetización del Mediterráneo occidental (Madrid 2000), 75-88; Hoyos 2003, op. cit. (n. 1), 55ff.; S.F. Ramallo Asensio, 'Carthago Nova. Arqueología y epigrafía de la muralla urbana’, in A. Morillo, F. Cadiou \& D. Hourcade, eds., Defensa y territorio en Hispania de los Escipiones a Augusto. Espacios urbanos y rurales, municipales y provinciales. Coloquio celebrado en la Casa de Velázquez 19 y 20 de marzo de 2001 (Madrid \& León 2003), 325-362.

${ }_{46}$ Hoyos 2003, op. cit. (n. 1), 134-151.

47 F.X. Hernández, Història militar de Catalunya I. Dels íbers als carolingis (Barcelona 2003), 43ff.; A. Goldsworthy, Las Guerras Púnicas (Barcelona 2002), 290ff.; $317 f f$. 
and communities, but also stress the renewal of ties that probably existed already before the arrival of Roman armies in Spain. ${ }^{48}$ Roman diplomacy, however, was not always that successful. Recently, particular attention has been devoted to the problems created by the troublesome policy of ad hoc recruitments of native auxiliaries, whose loyalty was never completely secure. The notorious disaster of 211 offers a dramatic example, as, if Livius is to be believed, the two Scipio brothers perished after being betrayed by some Celtiberian allies who had been seduced by Carthaginian gold. ${ }^{49}$

Before being sent to the front, the Roman legionaries and their Latin auxiliaries who arrived on a regular basis probably either stayed in temporary seaside camps, or were billeted on native towns that had already been secured with Roman garrisons. At the same time, the armies that were fighting inland moved back to this rearguard to winter or await embarkation for Italy in the spring. Recently, P. Erdkamp cogently argued that Republican armies could not simply live off the land and depended on a steady flow of supplies from outside. ${ }^{50}$ To our thinking, however, the specific nature of the Roman military presence in Spain, comprising a mobile front and a secured hinterland, required flexible lines of supply that drew from both local and external resources.

All of this unavoidably implies that the Roman military activity put some very heavy strains on the native population, in terms of both human and material costs. ${ }^{51}$ Under the guise of a series of political alliances between Rome and the pro-Roman factions among the local elites, surrendering native towns were subjected to demanding exactions of auxiliaries and war indemnities in the form of cash, weapons and other valuable goods. ${ }^{52}$ Even in case of occasional purchases, the prices

${ }^{48}$ E.g. the treaty with Sagunt, see Livius 21.60.4; Polybius 3.76.2.

${ }^{49}$ J.M. Roldán, Los hispanos en el ejército romano de época republicana (Salamanca 1993), 19-27; A. Canto, 'Ilorci, Scipionis rogus (Plinio, NH III, 9) y algunos problemas de la Segunda Guerra Púnica en Hispania', Rivista Storica dell'Antichità 29 (1999), 127-167; Roddaz 1998, op. cit. (n. 3), 341-358; B.D. Hoyos, 'Generals and Annalists: geographic and chronological obscurities in the Scipio's campaigns in Spain, 218-211 BG', Klio 83.1 (2001), 68-92.

${ }^{50}$ P. Erdkamp, Hunger and the sword. Warfare and food supply in Roman Republican wars 264-30 вс (Amsterdam 1998), 141ff.; P. Erdkamp, 'War and State Formation in the Roman Republic' (2006, in print). See more recently also C. Carreras Monfort, 'Aprovisionamiento del soldado romano en campaña: la figura del praefectus vehiculorum', Habis 35 (2004), 291-311.

${ }^{51}$ Livius 21.65.5; 21.65.7; 22.21.4; Polybius 3.76.2.

52 A. Prieto, 'L'espace social du pouvoir en Hispanie romaine', in E. Hermon (ed.), Pouvoir et “imperium" (III" av. J.-C.-I ${ }^{\text {er }}$ ap. J.-C.) (Naples 1995), 213-226; E. 
were still invariably set by the Senate..$^{53}$ As J.S. Richardson has pointed out, the requisitions that Romans started to collect from 218 should definitely not be considered as regular taxes. Although Richardson discerns a change in this pattern from around 180, when a direct tax (called stipendium) and a half tithe (vicensuma) might have been imposed ex s.c.,${ }^{54}$ there is no conclusive proof for this view. At least for the next century or so, the ongoing maintenance of the war economy policy as applied during the Second Punic War perfectly accounts for the amount of wealth arriving in Rome from Spain.

Both Roman and Carthaginian armies experienced similar difficulties in their regular provisioning from outside the Iberian Peninsula. After a series of disastrous defeats in Italy during the early stage of the Second Punic War, Roman public finances equally suffered from a shortage of manpower not directly involved in war activities. Rome not only lost appalling numbers of soldiers, but also of potential taxpayers and food producers. ${ }^{55}$ Ships with provisions regularly arrived in Tarraco until 217-216, ${ }^{56}$ when Hannibal's resounding victories generated an overall financial crisis. All of this forced the Senate to reassess the way its overseas legions were to be supplied in the near future, under potentially worsening conditions. In 216 and 215, the Senate discussed urgent and persistent demands from the Roman commanders in Spain, Sicily and Sardinia for adequate pay, food and clothing for their armies. In 215, the Scipiones indeed wrote to the Senate that, if need be, they could find ways to get pay from the Spaniards. Frumentum, uestimenta and everything for the crews, however, had to be sent from Rome, as usual. If not, both the army and the province would simply be lost. As the Senate subsequently duly arranged for the delivery of clothing,

García Riaza, Celtíberos y lusitanos frente a Roma: diplomacia y derecho de guerra (Vitoria-Gasteiz 2002), 33ff.; F. Quesada Sanz, 'La guerra en las comunidades ibéricas c. 237-c. 195 a.C.: un modelo interpretativo', in Morillo, Cadiou \& Hourcade 2003, op. cit. (n. 45), 101-156.

${ }^{53}$ Livius 43.2.12. For compulsory purchases of corn from Hispania, Sicily and Sardinia during the second and first centuries BGE, see Ñaco 2003, op. cit. (n. 38), $241 \mathrm{ff}$.

${ }^{54}$ Livius 40.35.4; 43.2.12; Richardson 1998, op. cit. (n. 40), $68 f f$.

${ }^{55}$ See Livius 23.48.7 and C. Nicolet, 'Armées et fiscalité: pour un bilan de la conquête romaine', in Armées et fiscalité dans le monde antique (Paris 1977), 435-454; C. Nicolet, Censeurs et publicains. Économie dans la Rome antique (Paris 2000), 80-91; 394-397; Y. LeBohec, Histoire militaire des Guerres Puniques (Paris 1996), 197ff.; N. Rosenstein, Rome at War. Farms, Families, and Death in the Middle Republic (Chapel Hill \& London 2004), 3-25.

${ }_{56}$ Polybius 3.106.7; Livius 22.22.1f.; J.S. Richardson 1986, op. cit. (n. 18), 42-43; $57-58$. 
grain and whatever else was needed for the crews, it is obvious that it authorized the proconsuls in Spain to exact pay from the local communities. ${ }^{57}$ Except for the extraordinary profits from looting and other occasional forms of income, most Roman legionaries only expected to receive a small part of their regular pay in coins, and especially in Roman coins, at the end of their yearly season of service, just before retiring to winter or going home, where more rewards were waiting. ${ }^{58}$ As only a few Spanish towns were striking coins by 218, it is clear that the huge increase in local coin circulation during the next two decades cannot be explained without taking into account the need of military pay. Instead of striking coins themselves in Spain, both contenders made use of local coinage, the Romans at Emporion and the Carthaginians at Malaka, Abdera or Gadir. Unlike the Carthaginian mercenaries, who probably expected to be paid in silver or gold, or at least in a strong currency, Roman and Italian soldiers received a fair share of their pay in the form of smaller bronze or copper denominations from any mint of their allies in the region, either native or Greek. At any rate, the fact that almost no such coins have been found in Italy strongly suggests that whatever wasn't spent on the local markets, was either exchanged just before departure for Italy, or melted down immediately after arrival home. ${ }^{59}$

In 23.48.4-49.4, Livius records that the Senate in 215 decreed some extraordinary measures to finance the provisioning of armies in Spain (food and clothing). To our thinking, P. Erdkamp probably rightly questions Livius' story about three societates of private citizens that contracted

${ }^{57}$ Livius 23.21; 23.31; 23.48-49. For Carthaginian generals requesting provisions and money to pay for their mercenaries in $217-216$, see Livius $22.40 .6-9 ; 23.12 .4-5$; $26.2-3$.

${ }_{58}$ M.H. Crawford, Coinage and Money under the Roman Republic (London 1985), 72; N. Rosenstein, 'Republican Rome', in K. Raaflaub \& N. Rosenstein, eds., War and Society in the Ancient and Medieval World. Asia, the Mediterranean, Europe, and Mesoamerica (Cambridge MA 1999), 193-216; T.M. Lucchelli, 'Cultura della moneta ed espansione romana in Europa', Rivista Italiana di Numismatica e Scienze Affini 101 (2000), 75-91; D. Potter, 'The Roman Army and Navy', in H.I. Flower (ed.), The Cambridge Companion to the Roman Republic (Cambridge 2004), 66-88.

${ }_{59}$ G. Alfaro et al., Historia monetaria de Hispania antigua (Madrid 1997), 40ff.; 70ff;; F. Chaves 'Moneda, territorio y administración. Hispania Ulterior de los inicios de la conquista al final del siglo II a.C.', in Moneda i administració del territori. IV Curs d'Història Monetària d'Hispània (Barcelona 2000), 9-35; M. Campo, 'La producció d'Untikesken i Kese: funció i producció a la ciutat i al territori', in Funció i producció de les seques indígenes. VI Curs d'Història Monetària d'Hispània (Barcelona 2002), 77-104. 
to supply the Scipionic armies. ${ }^{60}$ As a matter of fact, there is not much evidence for the kind of activities described by Livius on the part of societates publicanorum in the Western Mediterranean for nearly a century, with the exception, perhaps, of an inscription of $c a .150$ from Karales in Sardinia (CIL I ${ }^{2} 2226$; ILLRP 41), or some lead bricks and other coin material from the Southern Spanish mines dating from the very end of the second century BGE or the very outset of the next one. ${ }^{61}$ Although this evidence may seem too marginal to be taken as a serious indicator, and difficulties in applying the term publicani to the people concerned persist, some privati might indeed have become involved in the military provisioning in the course of the Spanish campaigns, like the redemptores who were expelled from camp by M. Porcius Cato as praetor in 198 in Sardinia and as consul in 195 in Emporion. ${ }^{62}$

From 218 to 206, the redirection of Carthaginian resources in Spain to its own armies had been one of Rome's foremost priorities in Spain. From 206, however, the Iberian Peninsula temporarily became the consistently unstable hinterland of the African front. When the Second Macedonian War finally broke out in 200, the focal point shifted even further East, troops and resources being now diverted to that major theatre of war. ${ }^{63}$ Livius' mention of two batches of corn from Spain to the Roman army in Africa and Rome itself in 203 indeed illustrates how resources of provincial communities were tapped and used at Rome's discretion. ${ }^{64}$ In any case, Rome's treatment of local communities left

${ }^{60}$ Crawford 1985, op. cit. (n. 58), 58; Ma.P. García-Bellido, 'El proceso de monetización en el Levante y Sur hispánico durante la Segunda Guerra Púnica', in J. Untermann \& F. Villar, eds., Lengua y cultura en la Hispania prerromana (Salamanca 1993), 317-347; Erdkamp 1998, op. cit. (n. 50), 86ff.; 114 (“a rather dubious story"); J.P. Roth, The Logistics of the Roman Army at War 264 BC-AD 235 (Leiden, Boston \& Köln 1999), 224ff.; O. Marra, 'Il vittoriato: sua circolazione e funzione all'interno del sistema monetario romano', Rivista Italiana di Numismatica e Scienze Affini 102 (2001), 106-110.

${ }_{61}$ R. Zucca, 'Inscriptiones latinae liberae rei publicae Africae, Sardiniae et Corsicae', in L'Africa Romana. Atti del XI Convenio di Studio (Sassari 1996), 1487; F. Chaves \& P. Otero, 'Los hallazgos monetales', in J.M. Blázquez, C. Domergue \& P. Sillières, eds., La Loba. Fuenteobejuna, province de Cordoue, Espagne (Bordeaux 2002), 163-230.

${ }^{62}$ Livius 34.9.12; Plutarchus Cato Maior 5.2; P. Erdkamp, 'Feeding Rome, or Feeding Mars? A long-term approach to C. Gracchus' Lex Frumentaria', Ancient Society 30 (2000), 59ff.; Naco 2003, op. cit. (n. 38), 124-126.

${ }^{63}$ P. LeRoux, Romains d'Espagne. Cités \& politique dans les provinces. II siècle av. J.-C.-III siècle ap. J.-C. (Paris 1995), 35ff.; K. Buraselis, 'Vix aerarium sufficeret. Roman finances and the outbreak of the Second Macedonian War', Greek, Roman and Byzantine Studies 37.2 (1996), 149-172; Naco 2003, op. cit. (n. 38), 139ff.

64 Livius 30.3.2-3; 25.5-6. 
no room for interpretation as to what their relationship to the new foreign intruder was, and made it quite clear that the Roman presence might be a long standing one. As the increasing cost of maintaining considerable forces overseas could only be covered for by the profits of conquest, ${ }^{65}$ the Roman commanders in Spain soon realized the actual advantages of recurrent and relatively short but intense campaigns. It indeed regularly occurred that Roman generals mounted military action just before being relieved of their commands, resulting in a surplus of booty, war prisoners and honours, key contributors to a successful political career in Rome ${ }^{66}$ Besides, in addition to the natural principle that a motivated army requires punctual pay, the mutiny in the Roman camp of Sucro in 206 also demonstrates that prolonged inactivity was not in the interest of maintaining discipline among the legionaries. ${ }^{67}$ Finally, it is important to emphasize that the spoils of war were of vital importance to the Roman rank and file, too. Apart from the fact that booty provided them with the material means for limited social mobility, regular pay could never fully compensate the soldiers for leaving their farms for prolonged periods of time. ${ }^{68}$

Concerning the methods applied by the Roman commanders in the field to secure and extend Rome's stronghold over Spain, it is important to point out that some of the measures taken during the first years of Roman intervention would become permanent features of the Roman military presence throughout the whole conquest of the Iberian Peninsula. In 28.34.7, Livius indeed records that,

The old custom of the Romans in establishing peaceful relations with a people neither on the basis of a treaty nor on equal terms had been this: not to exert its authority over that people, as now pacified, until it

${ }^{65}$ As has been conclusively demonstrated with respect to the annexation of Macedonia fifty years later by W.V. Harris, War and Imperialism in the Roman Republic 327-70 вC (Oxford 1979), 74ff.

${ }^{66}$ This practice seems to have been an unwritten law in the Roman administration of Spain; see Livius 39.29.5; 40.33 .9 and Naco 2003, op. cit. (n. 38), 153-155.

${ }_{67}$ Zonaras 9.10; Livius 28.25.6; 28.25.9-10; 27.1-5; Appianus Iberica 34-36; Polybius 11.25.9; 26.1-3; 28.7-8. S.G. Chrissanthos 'Scipio and the mutiny at Sucro, 206 вс', Historia 46.2 (1997), 172-184; Ñaco 2003, op. cit. (n. 38), 134-138.

${ }^{68}$ M. Tarpin, 'Le butin sonnant et trébuchant dans la Rome républicaine', in J. Andreau (ed.), Économie antique. La guerre dans les économies antiques. Entretiens d'archéologie et d'histoire (Saint-Bertrand-de-Comminges 2000), 365-376; C. Auliard, Victoires et triomphes à Rome (Paris 2001), 27ff.; 90ff. 
had surrendered everything divine and human, until hostages had been received, arms taken away and garrisons posted in its cities. ${ }^{69}$

In 28.42.2-4, Livius indeed describes how P. Scipio Africanus was able to move from Tarraco to the river Iberus in 206 through an elaborate network of Roman garrisons spread all over the coastline: "From Tarraco it was then a march from one Roman post to another (per praesidia)". Tarraco, according to Plinius Maior 'Scipionum opus' (Naturalis Historia 3.21), was where Gnaeus Scipio had wintered for the first time in 218/217, pending the arrival of his brother Publius (Polybius 3.76.12f.). Both Roman commanders may have been responsible for the establishment of what Livius calls a praesidium modicum (21.61.4), a modest garrison, probably set up in a sort of small fort identified by archaeologists on top of the hill opposite the Iberian Iron Age site by the sea. ${ }^{70}$

Ever since, the Romans consistently extended a network of garrisons in Spain. The first aim doubtlessly was to safeguard the more or less pacified hinterland and to facilitate auxiliary recruitment. Secondly, these strongholds must have served as provisioning stations for the armies that were doing the actual fighting. Unfortunately, however, there is no archaeological evidence for most of those early outposts, forts, or even full-fledged army camps, like the one the consul M. Porcius Cato reportedly built near Emporion in 195. Fifty years later, the siege of Numantia offers another unambiguous example of how complete military camps were built if need be. ${ }^{71}$ At any rate, archaeologists have recently traced some evidence of small fortifications, perhaps to be identified with the castella of later periods. ${ }^{72}$ Attested in the Northeast, the Ebro valley and Lusitania but only occupied for limited periods of

${ }^{69}$ Livius 28.34.7: Mos uetustus erat Romanis, cum quo nec foedere nec aequis legibus iungeretur amicitia, non prius imperio in eum tamquam pacatum uti quam omnia diuina humanaque dedidisset, obsides accepti, arma adempta, praesidia urbibus impositum forent.

${ }^{70}$ P. Otiña \& J. Ruiz de Arbulo, 'De Cese a Tarraco. Evidencias y reflexiones sobre la Tarragona ibérica y el proceso de romanización', Empúries 52 (2000), 107-136; I. Arrayás, 'Tarraco, capital provincial', Gerión 22.1 (2004), 291-303; I. Arrayás, Morfología histórica del territorium de Tarraco en época tardo-republicana ss.III-I a.C. (Barcelona 2006, in print).

71 J. Pamment Salvatore, Roman Republican Castrametation. A reappraisal of historical and archaeological sources (Oxford 1996) $31 \mathrm{ff}$.

72 A. Morillo 'Los establecimientos militares temporales: conquista y defensa del territorio en la Hispania republicana', in Morillo, Cadiou \& Hourcade 2003, op. cit. (n. 45), 41-80. For Cato's army camp at Emporion, see Livius 34.9.11f. 
time from late second to early first century BCE, they could have played a role in road building, weaponry manufacture or recruitment and the training of native auxiliaries. In restive areas, however, they might have provided the campaigning legions with vital logistic support. ${ }^{73}$

Despite the lack of archaeological evidence, the extant literary accounts of the Second Punic War and its aftermath clearly show that the allocation of garrisons in native towns severely affected the daily lives of their inhabitants. Though the commanders of the Roman garrisons (mostly praefecti) were definitely accountable to the (pro)magistrate, they could easily overrule local authorities if necessary, as the events in Gades between 206 and 199 seem to suggest. ${ }^{74}$ When this ancient Phoenician town changed sides just before the Carthaginians were driven out of Spain once and for all, L. Marcius, the Roman commander involved, offered a treaty in return, although there could of course be no foedus legitimum until formal ratification by $S P Q R$. Significantly enough, L. Marcius only took diplomatic steps after having accepted the town's unconditional surrender. The Gaditans duly accepted a small garrison under a Roman prefect, whose subsequent activities made them formally complain before the Senate seven years later. In 171, yet another embassy of Hispani from both provinces equally complained about the misconduct of the praefecti put in charge of their towns. ${ }^{75}$

Contrary to what is sometimes believed there is no evidence whatsoever to assume the proclamation of a lex provinciae in 198/197, regulating subsequent administrative and juridical procedures in Spain. ${ }^{76}$ As argued in the first part of this paper, the Senate only decided to normalize the command structure in that Spain was henceforth to be governed by

${ }^{73}$ Appianus Iberica 38; Livius 21.48.8-10; 21.61.2; Polybius 3.69; 75.5. Knapp 1977, op. cit. (n. 3), 15-35; García Riaza 2002, op. cit. (n. 52), 204-214; F. Cadiou, 'Garnisons et camps permanents: un réseau défensif des territoires provinciaux dans l'Hispanie républicaine?', in Morillo, Cadiou \& Hourcade 2003, op. cit. (n. 45), 81-100.

${ }_{74}$ Cicero, Pro Balbo 34.39; Livius 32.2.5.

${ }^{75}$ Livius 43.2. See also J. Muñiz Coello, El proceso de repetundis del 171 a.de C. Livio, XLIII,2 (Huelva 1981), 44-51; J.L. Castro, 'El Foedus de Gadir del 206 a.C.: una revisión', Florentia Iliberritana 2 (1991), 269-280; Ñaco 2003, op. cit. (n. 38), 142.

${ }^{76}$ J. Muñiz Coello, El sistema fiscal en la España romana. República y Alto Imperio (Zaragoza 1982), 50-51; Richardson 1986, op. cit. (n. 18), see Livius 32.27.6; $28.2-3 ; 32.28 .11-12$. For the lex prouinciae as being really an edict issued by the Roman imperator, often, but not always, on the binding advice of decem legati cum auctoritate ex s.c., see B.D. Hoyos, 'Lex Provinciae and Governor's edict', Antichthon 7 (1973), 47-53. 
regular (pro)magistrates instead of extraordinary proconsuls. ${ }^{77}$ Barely a few months after the arrival of the two praetors, however, a general uprising broke out in Hispania Ulterior, quickly spreading to other parts of occupied Spain. As there is any indication that the Romans simply maintained their war economy policies in Spain, regardless of the regularization of the supreme command, it would be at best misleading to term this insurrection a 'fiscal revolt'. It should rather be seen an ad hoc coalition of towns and peoples against Rome's ongoing and punitive military presence in the region. ${ }^{78}$ As shown above, Rome's armies maintained Roman control by means of raiding the native communities, or by imposing all kinds of harsh exactions, demanding hostages, war indemnities and other occasional contributions in cash, precious metals, supplies, auxiliaries, etc. It took the Romans two years and, eventually, a genuine consular army to quell this revolt and restore Roman law and order in the area. Quite unsurprisingly, new trouble arose quite soon after the departure of M. Porcius Cato (cos. 195), this pattern of endemic warfare, reverse and expansion persisting until well into the reign of Caesar Augustus. ${ }^{79}$

77 See also J.S. Richardson, 'The administration of the empire', in Cambridge Ancient History IX (Cambridge 1994, 2nd ed.), 564-598; Brennan 2000, op. cit. (n. 3), 154-181; 313-322.

${ }_{78}^{78}$ Livius 33.21.7-8; 33.25.9-10; C. González Román, 'Control romano y resistencia indígena en los orígenes de la Bética', in Actas del II Congreso de historia de Andalucía. Historia Antigua (Córdoba 1994), 131-147.

${ }^{79}$ Appianus Iberica 42; Livius 35.1.1-4; Ñaco 2003, op. cit. (n. 38), 143ff. 